\title{
POLISH LANGUAGE IN KALININGRAD (RUSSIA) AT THE BEGINNING OF THE 21TH CENTURY - FOREIGN, SECOND OR NATIVE LANGUAGE?
}

\author{
Língua Polonesa em Kaliningrado (Rússia) no Início do Século 21 - \\ Lingua Estrangeira, Segunda Língua ou Lingua Materna?
}

\author{
Małgorzata GROCHOWINA \\ Immanuel Kant Baltic Federal University in Kaliningrad \\ Universidade Federal Báltica Immanuel Kant \\ MGrokhovina@kantiana.ru \\ https://orcid.org/0000-0003-1210-3544 \\ Ekaterina ZUBRITSKAYA \\ Immanuel Kant Baltic Federal University in Kaliningrad \\ Universidade Federal Báltica Immanuel Kant \\ EZubritskaya@kantiana.ru \\ https://orcid.org/0000-0001-5902-7441
}

\begin{abstract}
The main purpose of the article is to present the situation of the Polish language in Kaliningrad, the main administrative centre of the Kaliningrad region, the westernmost territory of the Russian Federation. Polish has been present in this area for centuries as foreign, second or native language depending on the nationality and origin of its users. Currently, people who live in Kaliningrad, have an opportunity to learn Polish at three institutions of various types. They are Polish diaspora organizations, private language schools and language courses, and state educational institutions, with Immanuel Kant Baltic Federal University between them. This article presents the results of our research which aims to identify the status of the Polish language among the students who attend Polish classes. The survey took the form of questionnaires, was anonymous and voluntary, and involved people from each of the organizations mentioned above.
\end{abstract} KEYWORDS: Polish language in Russia; Polish as a foreign language; Polish as a second language; Polish Studies.

RESUMO: O principal objetivo do presente artigo é apresentar o estado da língua polonesa em Kaliningrado, o principal centro administrativo do oblast de Kaliningrado, território mais ocidental da Federação Russa. A língua polonesa é presente nessa região há séculos como língua estrangeira, segunda língua ou língua materna dependendo da nacionalidade e origem de seus usuários. Atualmente, os moradores de 
Kaliningrado podem estudar língua polonesa em três tipos diferentes de instituições. Elas são: organizações de descendentes de poloneses, escolas e cursos privados, bem como instituições nacionais de ensino, dentre as quais a Universidade Federal Báltica Immanuel Kant(Immanuel Kant Baltic Federal University). Nesse trabalho são apresentados os resultados das nossas pesquisas, que têm como objetivo definir o status da língua polonesa entre os alunos que frequentam aulas de língua polonesa. A pesquisa foi por meio de enquetes, respondidas anônima e voluntariamente por pessoas das instituições mencionadas acima. PALAVRAS-CHAVE: Língua polonesa na Rússia; Polonês como língua estrangeira; Polonês como segunda língua; Estudos poloneses.

Tradução do resumo: Milena Woitovicz Cardoso

STRESZCZENIE: Głównym celem artykułu jest przedstawienie stanu języka polskiego w Kaliningradzie, głównym ośrodku administracyjnym obwodu kaliningradzkiego, najbardziej wysuniętego na zachód terytorium Federacji Rosyjskiej. Język polski występuje na tym obszarze od wieków jako język obcy, drugi lub ojczysty w zależności od narodowości i pochodzenia jego użytkowników. Obecnie osoby mieszkające w Kaliningradzie mają możliwość nauki języka polskiego w trzech różnego typu placówkach. Są to organizacje polonijne, prywatne szkoły i kursy językowe oraz państwowe instytucje edukacyjne, w tym między innymi Bałtycki Uniwersytet Federalny im. Immanuela Kanta. W artykule przedstawiono wyniki naszych badań, których celem jest określenie statusu języka polskiego wśród uczniów uczęszczających na zajęcia z języka polskiego. Badanie miało formę ankiety, było anonimowe, dobrowolne $\mathrm{i}$ obejmowało osoby z każdej z wyżej wymienionych organizacji. SŁOWA KLUCZOWE: Język polski w Rosji; Język polski jako język obcy; Język polski jako drugi język; Studia Polskie.

Polish can be understood everywhere in Königsberg. There are many Poles among buyers ... and German buyers learn Polish to develop trade relations with Poland ... In the olden days Polish speech was much more valued here. (JASIŃSKI, 1994, p. 63)

Konigsberg is the former name of Kaliningrad and the presence of the Polish language in the area of the modern Kaliningrad Oblast (region) has been noticeable for centuries.

As the central city of the region Kaliningrad is an area of coexistence and interpenetration of many different cultures and languages. Special historical background, 
economy and geopolitical environment make this city unique. It is an exclave separated from the rest of Russia, located between Lithuania and Poland. The distance between Gdansk and Kaliningrad is considerably shorter $(150 \mathrm{~km})$ than the distance between Moscow and Kaliningrad (1200km). On the one hand, due to the specific geographical location, the Kaliningrad Region is perceived as a double periphery of both the Russian Federation and the European Union, on the other, it is called the "gate to Russia" (PALMOWSKI, 2013, p. 28-31).

It is worth mentioning that today this territory is inhabited by a population formed as a result of resettlements which took place after 1945. After the end of the Second World War, the German population was evacuated together with the retreating German army and forcibly displaced to Germany. The process of development of this area by USSR from spring 1945 to 1950 can be divided into several periods of influx of new inhabitants. The first group of Soviet people, who settled in conquered Konigsberg, consisted of demobilized soldiers of the Soviet army and fleet, who took part in hostilities in this area. The next group were residents of the Soviet Union, who were engaged in labour in Germany during the war and returned to their homeland. The third group of displaced population included engineers, specialists, workers and their families, who arrived here to rebuild a destroyed city and develop the economy. They were citizens of different Soviet Socialist Republics, mainly residents of Lithuania, Ukraine and Belarusian Soviet Socialist Republic. It might be assumed that the largest number of settlers, among whom some might have been Poles, came from the areas of present-day Belarus. Teachers, doctors, librarians and cinema operators were also directed to the oblast. They were usually young people with little work experience. According to statistics people from 24 regions of the Russian Federal Soviet Socialist Republic, seven regions of Belarus and four autonomous republics were brought since 1947 to the Kaliningrad region (PALMOWSKI, 2013, p. 106).

It should be noted that the main condition taken into account when selecting families for resettlement, was the presence of at least two people in the family who were able to work (KOSTYASHOV, 1996, p. 83). Moreover, the proximity of the previous place of residence and the absence of housing destroyed by Nazi soldiers during the war (PALMOWSKI, 2013, p. 108) were also considered as reasons for the land settlement. Given that the Kaliningrad Oblast community was artificially formed, it can be claimed that its ethnicity reflects religious and national diversity of both the former USSR and modern Russia

Specific geographical historical and economic environment creates undoubted opportunities for the Polish language development in this area. Currently, people 
interested in the Polish language have an opportunity to choose between at least 3 different organizations that offer Polish language learning, namely:

- Polish diaspora organizations

- private language schools and language courses

- state educational institutions, including the Immanuel Kant Baltic Federal University.

\section{THE POLISH DIASPORA IN KALININGRAD}

Polish diaspora in the Kaliningrad region brings together descendants of immigrants from Lithuania, Ukraine and Belarus. The number of people of Polish origin significantly increased after the collapse of the USSR and relocation of citizens from Kazakhstan, where independence was asserted by that time. Some estimates indicate that since 1990 from 37 to over 120,000 inhabitants have come to Kaliningrad region from this country and about 300-500 might have been Poles (GALICKI, 2003, p. 7). According to official statistics based on the 2002 census, ethnic structure of the region is made up of 110 nationalities, 3,9 thousand Poles among them (ŻEGOTA, 2012, p. 268).

However, in 2020, according to official data made available by the Consulate General of the Republic of Poland in Kaliningrad, almost 2,000 people of Polish nationality live in the entire Kaliningrad Oblast, while the number of people of Polish origin is estimated at 7,000. These discrepancies, or underestimations, may stem from the declaration of belonging to the definite nationality which mainly depends on personal ethnic self-identification. It would have been reasonable to assume that the loss of national feelings and ethnic roots was determined by the national policy in the USSR aimed to create a new type of personality who belongs to the Soviet nation and who is absolutely free from any kind of nationalism. According to the Polish scientist, Halina Murawska, such policy has led to national indifference (MURAWSKA, 1997, p. 261).

Nowadays, the main Polish community centres are located in the towns of Baltiysk, Gusev, Oziersk, Znamiensk, Chernyakhovsk and Kaliningrad. As mentioned by Kleofas Lawrynowicz, one of the first organizers of local Polish community life, the first Community of Polish Culture was established in Kaliningrad in 1992. The initiator of establishing this association was a priest who came from Poland and worked there - Jerzy Steckiewicz. Thanks to his involvement it has become possible to bring together people who didn't know each other before, but were connected by memory of their ancestral land, their parents, cultural traditions and religious identity. It will be perceived that it 
was not without reason that the Polish community in Kaliningrad begins its activities with bringing people together in the chapel of St. Adalbert. The fact that Polish people started gathering in the church confirms the words of Professor Zofia Kurzowa that Catholicism is an excellent transmitter of the Polish language abroad (KURZOWA, 1990, p. 133).

Jan Kondrad became the first president of the association. The next chiefs of organisation were Andrei Shevchuk, Kleofas Lawrynowicz and Mikhail Achramowicz. Similar communities were also established at that time in Baltiysk, Gusev and Oziersk (LAWRYNOWICZ, 2007).

Currently, there are two Polish diaspora organizations in the centre of the Kaliningrad region - "The Polonez Youth Union" registered in 2014 (run by Ms Aleksandra Poźniakowa) and the "Polonia Nationality and Culture Autonomy of Poles", whose president is Elena Rogaczykowa. These associations bring together about 200 official members and supporters. The Polish language is taught in both organizations. In "The Polonez Youth Union", these are language classes conducted by volunteers (mainly students of Immanuel Kant Baltic Federal University) at the municipal public library, which is called after the prominent Russian writer Antony Chekhov. The classes are held once a week and currently 27 preschoolers attend them.

There is a Saturday school at Autonomy of Poles "Polonia", where classes for 30 children and teenagers are conducted, and on weekdays there are classes at different levels for 20 adults of Polish origin. It should be emphasized, however, that not all members of these organizations do participate in language courses, the majority of them are involved in cultural activities, preparing and participating in various concerts and recitation contests. The main purpose of these associations is not to learn or to develop the Polish language knowledge, but to support and develop Polish culture in the Kaliningrad region and to take part in various events.

\section{POLISH - FOREIGN, SECOND OR NATIVE LANGUAGE?}

Regardless of what is the goal of the projects realized by above mentioned associations, the Polish language is that ethnic and cultural substance which unites all participants. A Polish linguist Anna Seretny emphasizes that the meanings of the terms "native language" and "first language" are similar, as both of them refer to "the language first known and acquired by a human in the process of communication in their linguistic environment" (LIPIŃSKA, SERETNY, 2012, p. 20).

There is another term which refers to the concept of a first language. It is the 
national language, which is defined by Aleksander Szulc as "a set of social and regional variations of the language used by some language community (SZULC, 1994, p. 99). In turn, the notion of an inherited language refers to the method of determining the native language of emigrants used in the home environment, which is not an official or state language in the country of current residence. It can also be referred to as a home language (POLINSKY, KAGAN, 2007, p. 368).

Such terms as "language as a foreign" or "second language" appear in the context of mastering a non-native language. It is assumed that second language acquisition is learning a second language after a first language is already mastered or established. However, as didactics show, these processes do not have a completely separate course, but can also intertwine (LIPIŃSKA, SERETNY, 2012, p. 25). It should be noted that there is a special word for the Polish language which is used by people who are of Polish descent and usually live abroad. This word is "polonijny". The difference between "polonijny" and Polish is explained by Lipinska and Seretny as follows: "If the term "Polish language" outside of Poland may refer to Poles as well as to other nationalities, "Polonijny language", however, will apply only to people of Polish descent (LIPIŃSKA, SERETNY, 2012, p. 22-25).

Stanisław Dubisz distinguishes two basic spheres of Polish occurrence abroad. First of all, it is a sphere of continuation, modification and consolidation of knowledge, which is particularly related to Polish communities or ethnic groups in different countries of their residence. Secondly, it is the sphere of acquiring Polish and developing or improving it by representatives of other nationalities (DUBISZ, 1997a, p. 13). Most importantly, for members of Polish ethnic groups who live outside of Poland, Polish, in any functioning variation, is their ethnic language, which has a unifying function. As a result, as one of the basic values of their culture the Polish language plays a culture-forming role. It also enables the formation of social bonds and participation in ethnic culture, which is why it is endowed with cognitive and ethnic identification functions (DUBISZ, 1997b, p. 18).

According to Władysław Miodunka studies of Polish abroad can be divided into three categories:

- indigenous Polish ethnic communities, settlement and resettlement clusters, including Lithuania, Belarus, Russia, but also the Czech Republic or Slovakia;

- Polish continental communities, including Great Britain, Germany, the Netherlands, Italy, Belgium, France, Sweden;

- Polish overseas communities, the USA, Canada, Brazil, South Africa among them (MIODUNKA, 1990, p. 135). 


\section{"POLONIA" IN KALININGRAD}

The Kaliningrad Polonia certainly belongs to the indigenous Polish ethnic communities. The members of the Polish community organizations operating in the city took part in the study of the language of this community. Participation in the survey, which was conducted for the purposes of this article, was voluntary and anonymous. The questionnaire was available in electronic form and consisted of 15 single or multiplechoice closed questions. The questions were related to the Polish language issues, among them there were questions whether they perceive Polish as their native language, second or a foreign one.

People aged 15 to 55 took part in the survey. All respondents confirmed that they have Polish origin. They usually pointed out that the Pole was one of the greatgrandparents or grandparents, less often they were parents or people in the relationship with their great-grandmother.

It turned out that $40 \%$ of respondents consider Polish as their native language, $52 \%$ believe that their native language is Russian, while $8 \%$ identify these languages equally. Only $4 \%$ of them think that they speak Polish fluently, $8 \%$ choose the option very good, $52 \%$ good and $36 \%$ poor. Therefore, it seems that the respondents, despite their poor command of Polish, are emotionally related to them. Most of the respondents learned Polish on their own, the rest attended classes at a Saturday school or a private language school. It should be emphasized that this was a multiple-choice question and it was possible to select any number of options.

Respondents choose Russian as the language of communication at their home in $56 \%$ of the answers, while the remaining $44 \%$ indicate both Russian and Polish. It's remarkable that no one gives Polish as the only language used at home. When asked about their motivation to learn Polish, the vast majority of respondents say that they want to know the language and culture of their ancestors (84.6\%), 30.8\% explain that they learn Polish to receive a Polish Card and work in Poland, and a further 11.5\% want to study at Polish universities.

The reluctance to study in Poland may be due to the age of the participants, who took part in the survey, because only three of them were under 25. Similarly, it may be the issue of motivation to receive a Pole's Card, which may have been higher in the past, but some of participants have already obtained this document, so this is not their further motivation to learn.

The respondents maintain exposure to the Polish language by watching Polish TV 
programs (84\%), listening to Polish music (68\%), reading various texts in Polish (68\%). They less often communicate using the spoken language in conversations with native language users $(6 \%)$. As many as $25 \%$ of respondents use Polish for business purposes related to their work, but on the other hand, $28 \%$ are exposed to the Polish language only during language classes, whether at a Saturday school or a private language school.

Summing up the attitudes towards the Polish language among the Kaliningrad Polonia it is obvious that they are varied and most probably stem from the personal conditions and preferences of the respondents. However, the vast majority of respondents have a positive attitude towards Polish, considering it as their mother tongue even if they consider that they have mastered it poorly. We think that an important factor modeling a positive attitude towards the Polish language is the geographical proximity of Kaliningrad to the country of ancestors, which provides an opportunity to travel to Poland quite frequently or conduct vibrant business relations.

\section{PRIVATE SCHOOLS AND LANGUAGE COURSES}

In addition to Polish organizations, language classes are offered by private language schools. These classes are attended mostly by young Kaliningrad people interested in studying in Poland. It should be emphasized that these are people who do not have Polish origin and who justify the choice of the country of study planned by several factors:

- geographical proximity,

- lower fees related to studies (because the tuition fee in Russia is often higher),

- the opportunity to find a job in the EU,

- belonging of the Polish language to the group of Slavic languages, which suggests less difficulty in the process of language mastery.

In Kaliningrad there are three language schools specializing in teaching only Polish and several language schools in which teaching of the Polish language comes second or third after English and German in terms of the number of learners.

Apart from the above-mentioned group, people who cooperate with Polish business partners or visit Poland for tourism attend the Polish language courses. Since July 1, 2019, i.e. since the introduction of free electronic visas to Kaliningrad for Polish citizens and citizens of some other countries, an increase in interest to the Polish language has been observed in tourist industry. According to the data of the Russian Border Service in 2019 (data for October 1, 2019), the number of tourists from Poland increased by 65\%, which motivated the growing demand for Polish language in the tourism industry. 
Our research has shown that in October 2019, among private school students over $60 \%$ were students intending to begin their studies in Poland. Approximately $25 \%$ stated that they learn Polish for tourist purposes and argue this choice by saying that 'Poland is our neighbor, so it is worth teach neighbors' language. The next $10 \%$ motivated the choice of Polish language learning in private school by the purposes of obtaining a Polish Card and gaining some preferences. The last and the least group of Kaliningrad people learning Polish explained their choice with business purposes (approximately 5\%).

It should be noted that the growing demand for learning Polish in Kaliningrad has increased competition among private language schools and their teachers. To be competitive, private schools have to add to Polish language classes variety of additional activities: film screenings, discussion clubs, thematic meetings, culinary workshops, educational trips and different types of language competitions. This list does not cover all ideas that allow schools to fight for its place on the market and help students to get to know Polish language and Polish culture better.

Free language courses and the circles of Polish language lovers which are organized in public Kaliningrad libraries are also very popular among residents of different ages. Classes are usually run by volunteers and according the statistics the number of people willing to attend Polish classes usually exceeds significantly the number of volunteers and their possibilities.

In most schools and courses lecturers-volunteers are students or less often graduates of Polish studies at the Baltic Federal University of Immanuel Kant - the largest university in the region. It is the only university in the region that trains specialists in the field of Polish.

\section{STATE EDUCATIONAL INSTITUTIONS}

In addition to private language schools, Polish is taught in state-owned educational institutions, including:

- several high schools that organize classes as a second foreign language as part of an additional program; the first high school in Kaliningrad, which introduced teaching Polish language as foreign (JPJO further) in 1994, was junior high school No. 40;

- several universities (e.g., Russian University of Cooperation (Kaliningrad Branch), Russian Academy of National Economy and State Service (Western 
Branch), etc.) in the fields of "tourism", "customs law" etc. as a second foreign language;

- Immanuel Kant Baltic Federal University as a basic subject in the field of "Polish philology" and as a second foreign language in the fields of "tourism", "socio-cultural activity", "linguistics" and others.

Kaliningrad state educational institutions have much less motivational pragmatism in teaching JPJO. A leading position among these institutions is occupied by the Baltic Federal University of Immanuel Kant. In Russia, there are only three universities that educate professional Polish students with the right to teach Polish language and literature: Saint Petersburg State University, M. Lomonosov Moscow State University and I. Kant Baltic Federal University.

Kaliningrad Polish Studies was established in September 2000 at the Department of Slavic and Classical Languages as a result of the development of long-term cooperation (since the 1970s) of the Kaliningrad State University and Polish universities (primarily with the Pedagogical University in Olsztyn, currently - University of Warmia and Mazury). In 1993/94, a language course was organized at the university, which educated 72 people in 6 years, while the Polish language faculty in 204 years has graduated 204 specialists. Of these, according to our data, about 60 people have found employment in different educational institutions, state offices and cultural institutions (about 10), in Russian and Polish business companies operating on international market - over 70 people. Three graduates defended their doctoral dissertations (including two at the I. Kant Baltic Federal University: one in confrontational linguistics and the other in Polish literature) and another one at M. Lomonosov Moscow State University.

Since 2010 (as a result of Russia's accession to the Bologna system) Polish language education at the Baltic Federal University takes place at two levels: bachelor studies (4 years) and master studies (2 years). It should be emphasized, that no knowledge of the Polish language is required to enter the University, it's learning starts at level zero. Studies at the university include general learning of the modern Polish language and other Polish subjects: descriptive grammar, history of the language, Polish literature, history of Poland, etc. From the very beginning of studies, most subjects are taught in Polish.

Master's studies take place in the field of "Polish for professional purposes". You must be at least a B1 level to be admitted to this level of studies. The classes embrace various aspects of specialist languages (tourism language, language of law, business language) as well as disciplines developing the skills of masters students in the field 
of scientific research (research work, scientific seminar and others). Master's theses of students of Kaliningrad Polish studies are often reviewed by scientists from leading Polish universities.

Undergraduate and graduate students have classes in JPJO teaching methodology in the program, as well as carry out internships at a state school. Gymnasium No. 40, in which JPJO has been teaching for over 25 years, is the main institution of IKBFU students' teaching practices.

An important advantage of IKBFU Polish studies is the organization of language practices abroad, in Poland, which is compulsory condition for all undergraduate students. During the studies, internships take place twice: students leave for two weeks to Polish universities, such as Nicolaus Copernicus University in Torun, and University of Silesia in Katowice. In addition, students take part in summer schools or other forms of participation in Polish studies organized by NAWA (National Agency of Academic Mobility). One of the most popular student mobility programs is Erasmus + program.

Thanks to the support of the Polish Ministry of Education, from the very beginning of the language course, and since this time, Kaliningrad Polish studies always invite a teacher from Poland who combines professional skills with native user knowledge. Invited teacher conducts usually the classes in phonetics, Polish culture, functional styles and some others. Besides of these duties the teacher from Poland mediates in contacts with organizations supporting Polish culture outside Poland (e.g. the Foundation Help for Poles in the East, the General Consulate of the Republic of Poland in Kaliningrad), and takes an active part in organization of cultural events.

Since the establishment of the Polish language course, books have been gathered in a Polish language library at the University. Currently, this library has over a thousand volumes. These are monographs devoted to all areas of linguistics, fiction and literary criticism, but the most important part of the library embrace JPJO teaching textbooks at all levels. Almost all newest teaching textbooks that appear on the publishing market in Poland can be found in the Polish language library. Because access to this library is open to anyone interested, it is used not only by students, but also by JPJO teachers working in the Kaliningrad Oblast, who can view the latest textbooks and decide which ones to choose for work in their groups.

The basic textbook for teaching Polish for the 1st and 2nd year of undergraduate studies is, however, the textbook by prof. dr hab. Tatiana Szkapienko "Polish for fun". This manual has already had three editions (1999, 2012 and 2018) and is best suited to work in Russian-speaking groups. Thanks to the intended use of positive interference and 
interesting original methods of introducing the grammar and lexical material, students are immersed in Polish from the first class and start to communicate only in Polish.

In addition to traditional lectures and exercises, the education of future Polish language students takes place as part of extracurricular events organized at the university. It should be noted that they are all open to every interested resident of Kaliningrad and recitation, translation and methodological workshops are conducted by IKBFU specialists or by invited Polish lecturers for a wide audience. One of the most popular events on the calendar of Kaliningrad lovers of the Polish language are Polish Language Days, with the Polish Dictation as the main event. Every year the author of the dictation texts is prof. dr hab. Tatiana Szkapienko. For several years, dictation has a multimodal character when traditional text is combined with a picture on the slides of presentation. In March 2019, the dictation has taken place for the sixteenth time and was organized for the first time at an international level, because the participants from other cities of Russia, Ukraine and Slovakia could join the Kaliningrad participants thanks to new technologies.

As great evidence of high level of Kaliningrad Polish studies could be considered the awarding of the grant 'Polish Language Days in Kaliningrad' by the National Agency for Academic Mobility in 2019. This grant was given to IKBFU in partnership with the Nicolaus Copernicus University in Torun for the purposes of promotion of Polish language and culture in Kaliningrad region. The program of the grant includes lectures and workshops dedicated to Roman Ingarden, an outstanding Polish philosopher, professor at the Nicolaus Copernicus University in Torun, who translated the works of Immanuel Kant into Polish. Another direction of this project is the promotion of Polish painting. Within the framework of this program, the students involved must prepare in Polish short speeches, called by the organizers as Paint Talks (similarly to TEDtalks) and present to the public their favorite paintings of Polish artists.

All Polish language events organized at the university are open to all lovers of the Polish language, including members of Polish community organizations. In turn, Kaliningrad Polonia is an important partner of Polish studies: students (even those who do not have Polish origin) take part in Polish community events, and sometimes write bachelor's and master's theses based on the research of the Polish language.

The growing interest in Polish philology is evidenced by the recruitment data to Polish language studies: in 2016, it was 7 people; in 2018 - 13 people; but in 2019, 27 people were enrolled in Polish studies at IKBFU.

Summing up, we can say that Polish language is present in Kaliningrad not only because of the Poles and the Polish community who want to cultivate the language and 
traditions of the country of their origin, but also as the subject of steadily growing interest of the Russians who do not have relevant ethnic roots, but want to learn it due to specific geographical and economic conditions. The Kaliningrad city offers not only a wide range of language classes at various levels of language proficiency, but also a wide spectrum of events showing and promoting Polish culture. 


\section{BIBLIOGRAPHY:}

DUBISZ, S. Badania nad polszczyzną poza granicami kraju. In: DUBISZ, S. (Ed.) Język polski poza granicami kraju, Opole, Uniwersytet Opolski, 1997a. p. 13-18.

DUBISZ, S. Społeczne role polszczyzny poza granicami kraju. In: JANOWSKA, B.; PORAYSKI-POMSTA, J. (Eds.) Język polski w kraju i za granica, Warszawa: Elipsa, Uniwersytet Warszawski, 1997b. p. 17-21.

GALICKI, S. O naturze polskiej i o duchowości Polaków - przesiedlonych do Kazachstanu. In: Gtos Znad Pregoty (5), 2003. p. 5-9.

JASIŃSKI, J. Historia Królewca. Szkice z XIII - XX stulecia. Olsztyn: Książnica Polska, 1994.

KOSTYASHOV, J. Заселение Калининградской области после Второй мировой войны. In: Гуманитарная наука в России: соровские лауреаты. Москва: Международный научный фонд, 1996, vol. 2. p. 82-88.

KURZOWA, Z. Język polski w ZSRR. In: MIODUNKA, W. (Ed.) Język polski w świecie, Warszawa-Kraków, PWN, 1990. p. 127-144.

LIPIŃSKA, E.; SERETNY, A. Między językiem ojczystym a obcym. Kraków: Universitas, 2012.

MIODUNKA, W. Polszczyzna w środowiskach polonijnych. In: S. DUBISZ (Ed.) Język - Kultura - Społeczeństwo, Warszawa, 1990. p. 134-137.

MURAWSKA, H. Polacy w Kaliningradzie. In: Borussia, 1997, n.15.

PALMOWSKI, T. Kaliningrad - szansa czy zagrożenie dla Europy Battyckiej? Gdańsk: Uniwersytet Gdański, 2013.

POLINSKY, M.; KAGAN, O. Heritage Languages: In the 'Wild' and in the Classroom. Language and Linguistics Compass, 2007, n.1, p. 368-395.

SZULC, A. Słownik dydaktyki języków obcych. Warszawa: PWN, 1994.

ŻĘGOTA, K. Liczebność diaspory polskiej w Obwodzie Kaliningradzkim Federacji Rosyjskiej. Zarys problematyki, 2012. 


\section{INTERNET SOURCES:}

LAWRYNOWICZ, K.. Poliaki v Kaliningrade In: Baltijskij Vestnik (3). URL: $<$ https://www.klgd.ru/city/history/almanac/a3_17.php>, access 12.06.2020.

LAWRYNOWICZ, K... Jubileusz gazety - Głos znad Pregoły. URL: < https://www.polonia. org/przydatne-informacje/jubileusz-gazety-glos-znad-pregoly>, access 12.06.2020. 